\title{
RE-ESTABLISHING THE PATENCY OF THE HEPATIC VEIN AND THE PORTOSYSTEMIC SHUNT 10 YEARS AFTER THE TIPS PROCEDURE: A CLINICAL CASE
}

\author{
Tsitsiashvili MSh1, Shipovskiy VN ${ }^{1,2}$, Monakhov DV ${ }^{1,2}$, Chelyapin $\mathrm{AS}^{1,2}$, Huseynov $\mathrm{AB}^{1}$ \\ ${ }^{1}$ Pirogov Russian National Research Medical University, Moscow, Russia \\ ${ }^{2}$ Pletnev City Clinical Hospital, Moscow, Russia \\ Transjugular intrahepatic portosystemic shunt is one of the few available options for treating complications of portal hypertension in patients with chronic diffuse \\ liver diseases. Over time, shunt patency can become compromised, causing a recurrence of such complications. The clinical case presented below demonstrates \\ the potential of TIPS and illustrates the use of an endovascular reintervention for re-establishing shunt patency, which improves the life expectancy of patients, as \\ well as their quality of life.
}

Keywords: liver cirrhosis, portal hypertension, transjugular intrahepatic portosystemic shunt, dysfunction, reintervention

Author contribution: Chelyapin AS, Huseynov AB — study conception and design, data acquisition and processing; Chelyapin AS — statistical analysis; Tsitsiashvili MSh, Shipovskiy VN, Monakhov DV, Chelyapin AS, Huseynov AB — manuscript draft; Tsitsiashvili MSh — manuscript revision.

Compliance with ethical standards: the study was approved by the Ethics Committee of Pirogov Russian National Research Medical University (Protocol 170 dated December 18, 2017). Informed consent was obtained from all study participants.

$\triangle$ Correspondence should be addressed: Alexander Chelyapin

Ostrovityanova, 1, Moscow, 117997; ChelyapinAleks@yandex.ru

Received: 24.10.2019 Accepted: 08.11.2019 Published online: 16.11.2019

DOI: $10.24075 /$ brsmu.2019.074

\section{КЛИНИЧЕСКИЙ ПРИМЕР ВОССТАНОВЛЕНИЯ ПРОХОДИМОСТИ ПЕЧЕНОЧНОЙ ВЕНЫ И ПОРТОСИСТЕМНОГО ШУНТА ЧЕРЕЗ 10 ЛЕТ ПОСЛЕ ТІРS}

\author{
М. Ш. Цициашвили ${ }^{1}$ В. Н. Шиповскийํ, , Д. В. Монахов ${ }^{1,2}$, А. С. Челяпин ${ }^{1,2} \bowtie$, А. Б. Гусейнов ${ }^{1}$ \\ ${ }_{1}^{1}$ Российский национальный исследовательский университет имени Н. И. Пирогова, Москва, Россия \\ 2 Городская клиническая больница имени Д. Д. Плетнева, Москва, Россия
}

\begin{abstract}
Одним из немногих доступных методов борьбы с осложнениями портальной гипертензии у пациентов с хроническими диффузными заболеваниями печени является трансъюгулярное портосистемное шунтирование. С течением времени имеется тенденция к развитию диссрункции внутрипеченочного шунта вследствие нарушения его проходимости, что вновь приводит к развитию осложнений портальной гипертензии. Описанный клинический случай демонстрирует возможности внутрипеченочного шунтирования, а также повторных эндоваскулярных вмешательств при диссункции шунта, позволяющих значительно продлить жизнь пациента и сохранить ее качество.
\end{abstract}

Ключевые слова: цирроз печени, портальная гипертензия, трансъюгулярное внутрипеченочное портосистемное шунтирование, дисфункция, реинтервенция

Информация о вкладе авторов: А. С. Челяпин, А. Б. Гусейнов - концепция и дизайн исследования, сбор и обработка материала; А. С. Челяпин статистическая обработка данных; М. Ш. Цициашвили, В. Н. Шиповский, Д. В. Монахов, А. С. Челяпин, А. Б. Гусейнов - написание текста; М. Ш. Цициашвили - редактирование.

Соблюдение этических стандартов: работа одобрена этическим комитетом РНИМУ им. Н. И. Пирогова (протокол № 170 от 18 декабря 2017 г.). Все участники исследования подписали информированное согласие на участие в исследовании

$凶$ Для корреспонденции: Александр Сергеевич Челяпин

ул. Островитянова, д. 1, г. Москва, 117997; ChelyapinAleks@yandex.ru

Статья получена: 24.10.2019 Статья принята к печати: 08.11.2019 Опубликована онлайн: 16.11.2019

DOI: $10.24075 /$ vrgmu.2019.074

Bleeding from esophageal (EVs) and gastric (GVs) varices is a life-threatening complication of portal hypertension. Mortality rates associated with first-time variceal hemorrhages and rebleeds are $50 \%$ and $70 \%$, respectively $[1,2]$. To reduce mortality, a special algorithm has been developed in Russia; it is detailed in the "clinical practice guidelines on the management of bleeding esophageal and gastric varices" [3]. According to this algorithm, endoscopic band ligation following emergency esophagogastroduodenoscopy (EGD) should be preferred over other endoscopic interventions because it allows achieving hemostasis in $80 \%$ of patients with refractory bleeding [3]. However, this treatment option works most effectively as primary prophylaxis for variceal bleeding and does not relieve portal pressure. Late recurrence of EVs and rebleeds occur in 50-60\% of patients undergoing band ligation [4]. This necessitates the use of alternative treatments in relapsed patients, such as portosystemic shunts that relieve pressure in the portal venous system and azygoportal disconnection. Of all portosystemic shunting options, transjugular intrahepatic portosystemic shunt (TIPS) is the treatment of choice for patients with class B/C cirrhosis. So far, we have performed 226 TIPS procedures in our clinic.

Intrahepatic shunt dysfunction can result in the recurrence of complications associated with portal hypertension and, therefore, is a relevant clinical problem [5-8]. Poor shunt patency can be caused by shunt thrombosis and pseudointimal hyperplasia, intimal hyperplasia of the hepatic vein, compression of the stent by high-density liver tissue, migration or disengagement of shunt components. On average, a shunt created from a stent-graft remains functional for 3-5 years; in extremely rare cases, it can retain its patency for up to 10 years.

To date, there are a variety of different endovascular techniques for restoring shunt patency. They help to extend the life of the shunt, reduce the risk of complications associated with portal hypertension and improve life expectancy in patients with end-stage diffuse chronic liver diseases. 
Below, we describe a case of TIPS revision 10 years after stent implantation in the liver parenchyma.

\section{Clinical case}

Patient K., 40 years, was diagnosed with liver cirrhosis (LC) complicated by portal hypertension in 2006 at the Central Research Institute of Gastroenterology (Moscow). On December 10, 2007 the patient was urgently admitted to the Surgery Unit No. 4 of the City Clinical Hospital № 57 (Moscow). Diagnosis on admission: liver cirrhosis (class B on the ChildPugh score) complicated by portal hypertension and recent grade III esophageal variceal bleeding.

The patient's condition was assessed as moderate. On physical examination, there was pallor and mild scleral icterus. Normal vesicular breathing was heard over both lungs. The respiratory rate was 14 breaths per minute. Heart tones were muffled. Blood pressure was 110/70. The patient's heart rate was 96 beats per minute. The abdomen was soft and nontender. The liver edge extended $3 \mathrm{~cm}$ below the costal margin. The patient showed no signs of urinary tract pathology.

Instrumental examinations revealed the following signs of portal hypertension: dilated portal $(14 \mathrm{~mm})$ and splenic $(9 \mathrm{~mm})$ veins, hepatosplenomegaly, grade III EVs. Blood tests revealed mild posthemorrhagic anemia (hemoglobin < $96 \mathrm{~g} / \mathrm{L}$ ), low red blood cell count $\left(3.89 \times 10^{12} / \mathrm{L}\right)$, low platelet count $\left(102 \times 10^{9} / \mathrm{L}\right)$, and unconjugated hyperbilirubinemia $(34 \mu \mathrm{mol} / \mathrm{L})$. The coagulation test came back normal.

On day 2 after admission to the hospital, there was a recurrence of gastrointestinal variceal bleeding confirmed by EGD. The bleeding was stopped using a SengstakenBlakemore tube. The patient was transferred to the Intensive Care Unit. Follow-up EGD revealed engorged varices $(7-9 \mathrm{~mm}$ in diameter) in the middle and lower thirds of the esophagus. The mucosa above the varices was cyanotic-looking, with an overlayer of hemin. To reduce the risk of rebleeds, endoscopic band ligation was performed first on December 17, 2007; a total of 20 ligatures were placed. In the second step, on December 19, 2007 the patient underwent TIPS with a Viatorr TIPS Endoprosthesis stent-graft (Gore; USA). Intraoperatively, the portal pressure decreased from 520 to $300 \mathrm{~mm} \mathrm{H}_{2} \mathrm{O}$.

The postoperative period was uneventful. On December 22, 2007, the patient underwent a Doppler ultrasound scan, which showed a normal blood flow throughout the entire length of the shunt with the intrashunt velocity of $85 \mathrm{~cm} / \mathrm{s}$. Postoperatively, the patient was receiving conventional medication therapy until he was stable; on December 25, 2007 the patient was discharged in a satisfactory condition.

In the 9-year follow-up period, the patient was hospitalized every 6 months to receive supportive therapy for his liver function. No clinical signs of complications associated with portal hypertension were observed during the entire follow-up period.

In December 2017 during one of such hospitalizations, a dupplex Doppler scan revealed a high-velocity flow in the proximal TIPS portion and a low-velocity flow in its distal segment, suggesting stenosis of the right hepatic vein (Fig. 1). EGD revealed grade III EVs indicative of the increasing pressure in the portal venous system.

In order to verify the diagnosis, a contrast-enhanced CT scan of the abdomen was performed, which confirmed stenosis of the right hepatic vein (Fig. 2).

Considering that there were signs of right hepatic vein stenosis, including the changed hemodynamics in the shunt and the portal vein (low velocity flow in the portal vein), as well

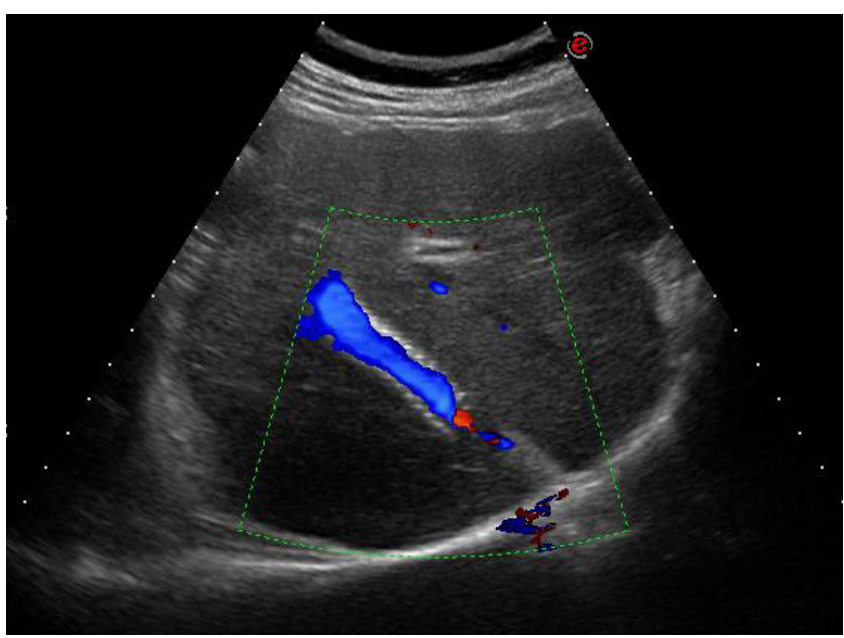

Fig. 1. Patient K. with class B liver cirrhosis, after TIPS. Stenosis of the proxima TIPS segment. Intrashunt velocity of $37 \mathrm{~cm} / \mathrm{s}$

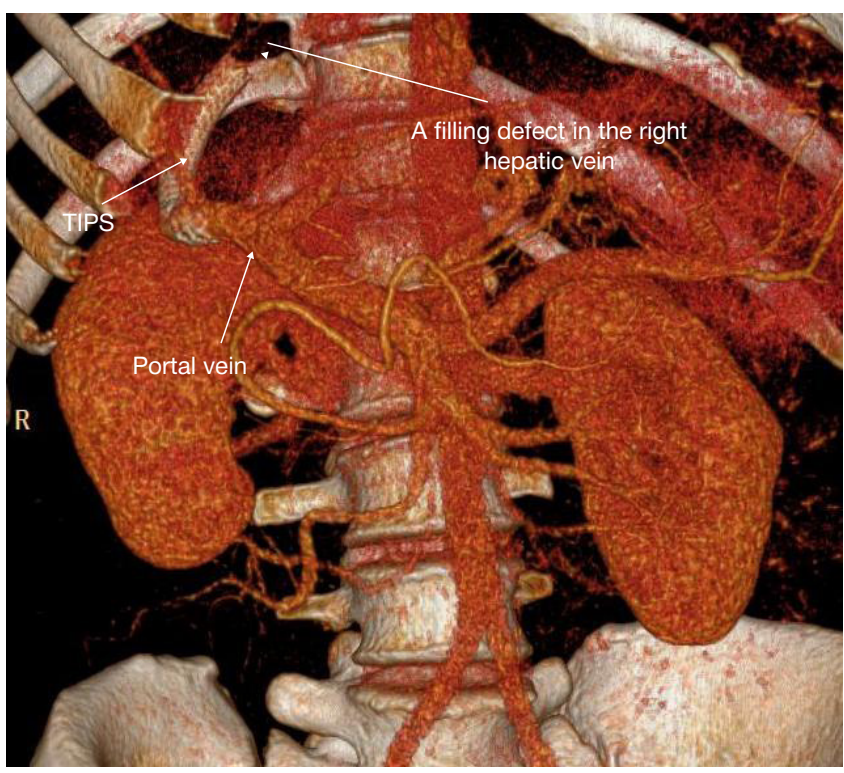

Fig. 2. A CT-angiography image showing intimal hyperplasia of the right hepatic vein

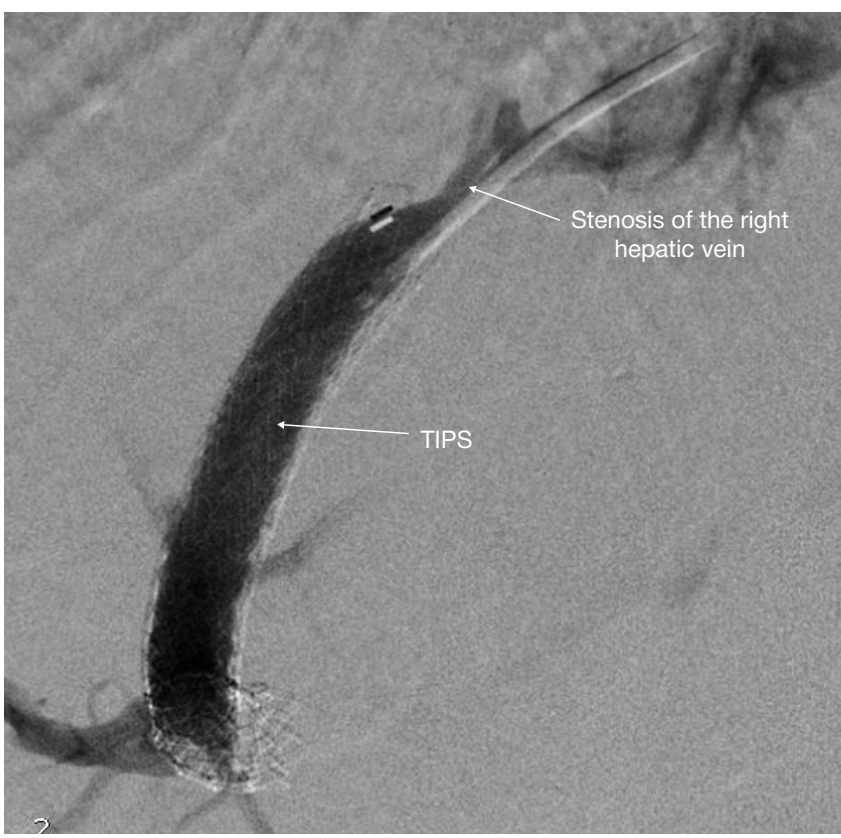

Fig. 3. Transjugular portal venogram of patient $K$ 

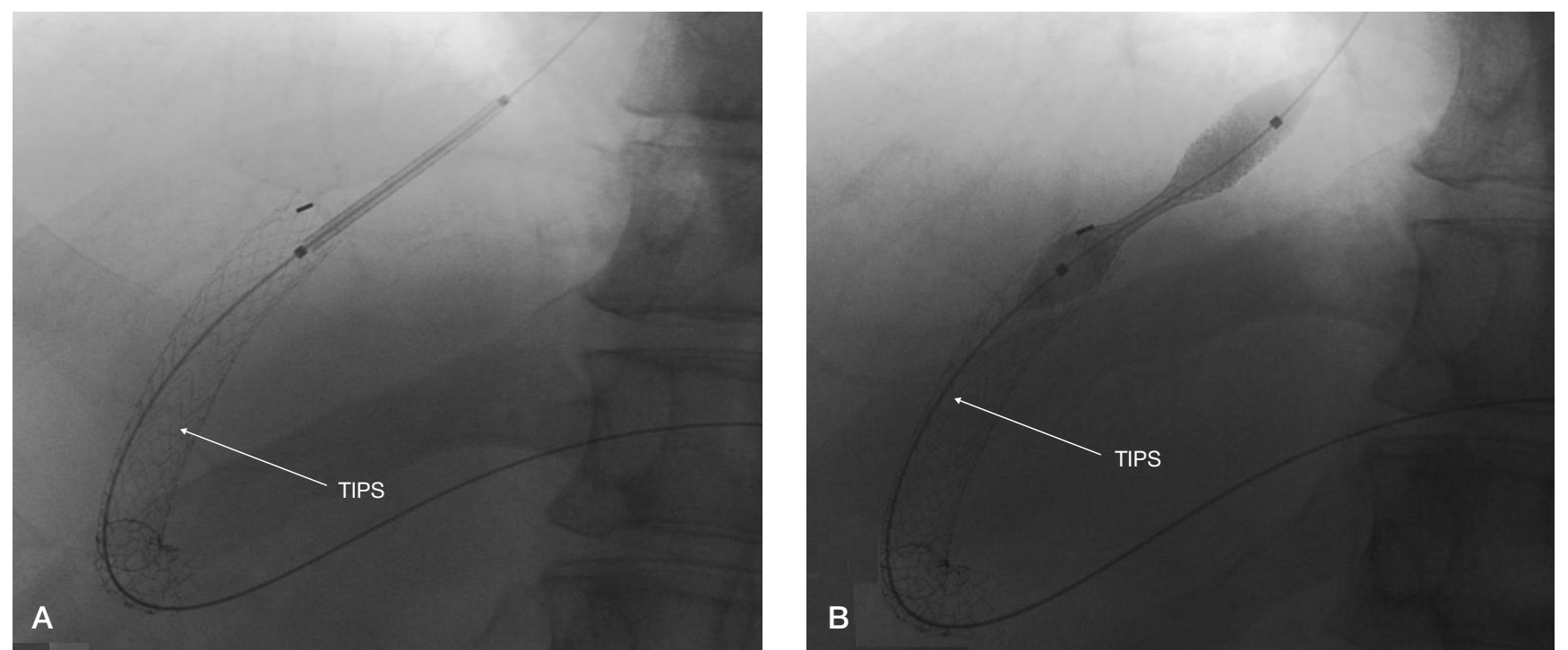

Fig. 4. Transjugular portal venogram of patient K. Stages of stent-in-stent placement. A. Stent implantation. B. Stent expansion

as progressing EVs, a decision was made to restore TIPS patency.

Stenosis was visualized by portal venography. After acquiring a portal venogram, it was decided to apply a stentin-stent technique (Fig. 3 and 4).

Follow-up portal venography performed after the procedure revealed that the patency of the transjugular intrahepatic shunt had been re-established; no signs of stenosis were present on the venogram (Fig. 5).

The postoperative period was uneventful. On the Doppler image of the portal system, the intrashunt flow was normal, with a velocity of $112 \mathrm{~cm} / \mathrm{s}$. The patient received a course of medication therapy for his liver and was discharged when his condition was found to be satisfactory.

Since the procedure, the patient has been undergoing regular checkups in our clinic. His last hospitalization took place in August 2019. So far, no complications associated with portal hypertension have arisen in this 2-year follow-up period.

\section{Discussion}

As we were analyzing the literature and our own clinical experience, we arrived at the conclusion that stent-grafts are the best option for creating intrahepatic shunts during a TIPS procedure. The use of stent- grafts reduces the risk of shunt thrombosis in the early postoperative period and the incidence of TIPS dysfunction in the late postoperative period [8, 9].

However, in spite of all advantages of stent-grafts, shunt patency can deteriorate over time due to stenosis caused by intimal hyperplasia of the right hepatic vein. To reduce the risk of this complication, the stent should be placed in the ostium of the right hepatic vein $[10,11]$.

The clinical case presented in this article demonstrates that reinterventions after TIPS, including placement of stents in the

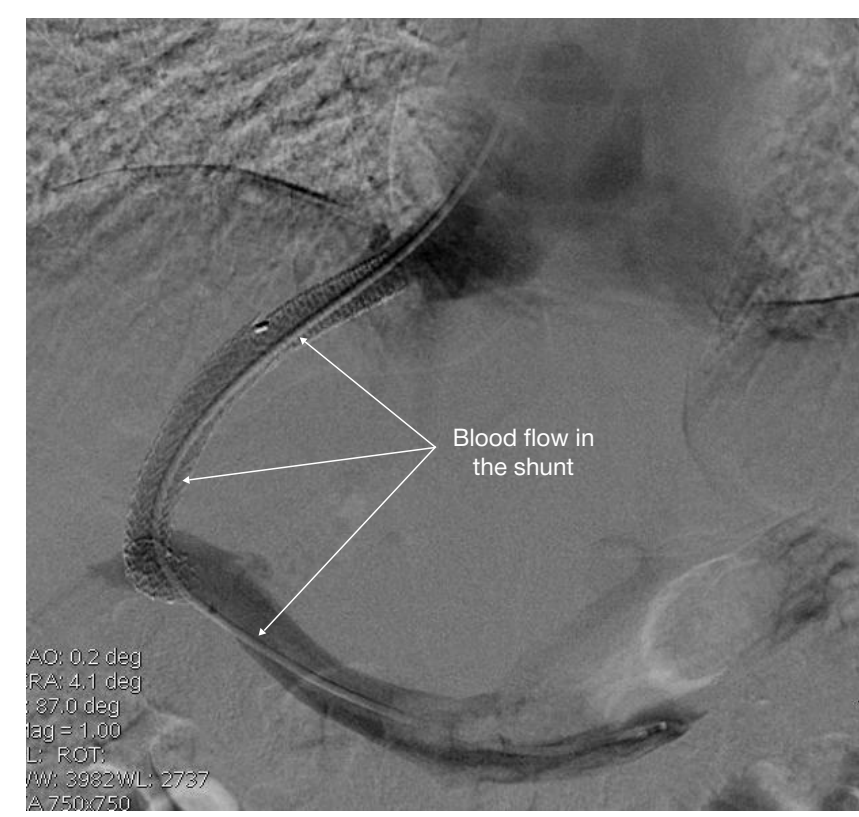

Fig. 5. Transjugular portal venogram of patient K. after TIPS revision and stentin-stent placement

right hepatic vein, reduce the risk of complications associated with portal hypertension, improve life expectancy of the affected patients and the quality of their lives.

\section{CONCLUSIONS}

Re-establishing the patency of a compromised intrahepatic shunt has serious implications. A long-lasting TIPS allows liver transplant candidates to be on the waiting list for quite a long time without being at risk for variceal bleeding.

\section{References}

1. Elsebaey MA, et al. Endoscopic injection sclerotherapy versus $\mathrm{N}$-Butyl-2 Cyanoacrylate injection in the management of actively bleeding esophageal varices: a randomized controlled trial. BMC gastroenterology. 2019; 19 (1): 23.

2. Shi L, et al. Favorable Effects of Endoscopic Ligation Combined with Drugs on Rebleeding and Mortality in Cirrhotic Patients: A Network Meta-Analysis. Digestive Diseases. 2018; 36 (2): 136-49.

3. Anisimov AYu, Vertkin AL, Devyatov AV, Dzidzava II, Zhigalova SB, Zatevakhin II, et al. Clinical guidelines on treatment of esophageal and stomach variceal bleeding. Available from: http://xn-- 
--9sbdbejx7bdduahou3a5d.xn--p1ai/stranica-pravlenija/unkr/ urgentnaja-abdominalnaja-hirurgija/klinicheskie-rekomendaci-polecheniyu-krovotechenii-iz-varikozno-rasshirenyh-ven-pischevodai-zheludka.html.

4. Masalaite L, Valantinas J, Stanaitis J. Endoscopic ultrasound findings predict the recurrence of esophageal varices after endoscopic band ligation: a prospective cohort study. Scandinavian journal of gastroenterology. 2015; 50 (11): 1322-30.

5. Bureau C, et al. Transjugular intrahepatic portosystemic shunts with covered stents increase transplant-free survival of patients with cirrhosis and recurrent ascites. Gastroenterology. 2017; 152 (1): 157-63.

6. Lv Y, Han G, Fan D. Thrombosis after transjugular intrahepatic portosystemic shunt: an ominous sign? AME Medical Journal. 2017; 2 (40)

7. $\mathrm{Li} \mathrm{YH}$, et al. Long-term shunt patency and overall survival of

\section{Литература}

1. Elsebaey MA, et al. Endoscopic injection sclerotherapy versus $\mathrm{N}$-Butyl-2 Cyanoacrylate injection in the management of actively bleeding esophageal varices: a randomized controlled trial. BMC gastroenterology. 2019; 19 (1): 23

2. Shi L, et al. Favorable Effects of Endoscopic Ligation Combined with Drugs on Rebleeding and Mortality in Cirrhotic Patients: A Network Meta-Analysis. Digestive Diseases. 2018; 36 (2): 136-49.

3. Анисимов А. Ю., Верткин А. Л., Девятов А. В., Дзидзава И. И., Жигалова С. Б., Затевахин И. И., и др. Клинические рекомендации по лечению кровотечений из варикознорасширенных вен пищевода и желудка. Доступно по ссылке: http://xn----9sbdbejx7bdduahou3a5d.xn--p1ai/stranica-pravlenija/ unkr/urgentnaja-abdominalnaja-hirurgija/klinicheskie-rekomendaci-polecheniyu-krovotechenii-iz-varikozno-rasshirenyh-ven-pischevoda-izheludka.html.

4. Masalaite L, Valantinas J, Stanaitis J. Endoscopic ultrasound findings predict the recurrence of esophageal varices after endoscopic band ligation: a prospective cohort study. Scandinavian journal of gastroenterology. 2015; 50 (11): 1322-30.

5. Bureau C, et al. Transjugular intrahepatic portosystemic shunts with covered stents increase transplant-free survival of patients transjugular intrahepatic portosystemic shunt placement using covered stents with bare stents versus covered stents alone // Clinical radiology. 2018; 73 (6): 580-7.

8. Saad WE. A. Portal Hypertension: Imaging, Diagnosis, and Endovascular Management. Thieme, 2017.

9. Luo, Xue-Feng, et al. Stent-Grafts for the Treatment of TIPS Dysfunction: Fluency Stent vs Wallgraft Stent. World Journal of Gastroenterology. 2013; 19 (30): 5000-5.

10. Wang Q, et al. Eight millimetre covered TIPS does not compromise shunt function but reduces hepatic encephalopathy in preventing variceal rebleeding. Journal of hepatology. 2017; 67 (3): 508-16.

11. Suhocki PV, et al. Transjugular intrahepatic portosystemic shun complications: prevention and management // Seminars in interventional radiology. Thieme Medical Publishers. 2015; 32 (2): 123-32.

with cirrhosis and recurrent ascites. Gastroenterology. 2017; 152 (1): 157-63

6. Lv Y, Han G, Fan D. Thrombosis after transjugular intrahepatic portosystemic shunt: an ominous sign? AME Medical Journal. 2017; 2 (40).

7. $\mathrm{Li} \mathrm{YH}$, et al. Long-term shunt patency and overall survival of transjugular intrahepatic portosystemic shunt placement using covered stents with bare stents versus covered stents alone // Clinical radiology. 2018; 73 (6): 580-7.

8. Saad WE. A. Portal Hypertension: Imaging, Diagnosis, and Endovascular Management. Thieme, 2017.

9. Luo, Xue-Feng, et al. Stent-Grafts for the Treatment of TIPS Dysfunction: Fluency Stent vs Wallgraft Stent. World Journal of Gastroenterology. 2013; 19 (30): 5000-5.

10. Wang Q, et al. Eight millimetre covered TIPS does not compromise shunt function but reduces hepatic encephalopathy in preventing variceal rebleeding. Journal of hepatology. 2017; 67 (3): 508-16.

11. Suhocki PV, et al. Transjugular intrahepatic portosystemic shunt complications: prevention and management // Seminars in interventional radiology. Thieme Medical Publishers. 2015; 32 (2): 123-32. 